\title{
THE ANTHROPOLOGY OF CHILDHOOD AS AN ACADEMIC COURSE (PART OF THE TEACHING SPECIALIZATION)
}

\author{
|Ryszard Waksmund, Dorota Michułka
Uniwersytet Wrocławski
}

\begin{abstract}
The article presents the theme which is connected with programme and syllabus of the department of teacher education and create a question what place the anthropology of child and childhood may take in Polish studies of the 21st century. After many years of laborious research on children's culture, children's folklore, ethnography of childhood, sociology of childhood, and children's pedagogy and psychology, after the discussions about "childhood reinvented" and many "breakthroughs" in studies about the interdisciplinary nature of such research (from Ellen Key's work, to Janusz Korczak, to Philippe Ariés and Paul Hazard), knowledge of children and youth's literature and of children's culture, eventually became a part of Polish studies' programmes at the university level.

In modern times, an additional source of materials are journals and memoirs, which help understand both traumatic and ludic experiences of the child better.

Traumatic experiences often appear to be taboo. A special place is reserved for children's reports of the Holocaust. Our times, which bring many threats to the young (crisis of family, drugs, sexual abuse, child prostitution, homelessness, religious sects, exploitation at work, excessive consumerism, Internet addiction, etc.), are a domain for sociology of childhood and adolescence.

Therefore, it seems that a new field of knowledge about childhood is needed, a field that takes into consideration the following, previously neglected aspects: historical, sociological, political-scientific, and ethnographic with the context of children's folklore, also indeterminacy of child's social role
\end{abstract}

Key words: Anthropology of childhood, children studies, anthropology of pedagogy, socjology of childhood, history of childhood, politics and ethnography of childhood, childrens culture

Streszczenie: Artykuł ma na celu pokazanie, jakie miejsce w akademickiej dydaktyce polonistycznej (w ramach programu specjalizacji nauczycielskiej) może zająć w XXI wieku przedmiot antropologia dziecka i dzieciństwa.

Po wielu latach żmudnych eksploracji kultury dziecka, dziecięcego folkloru, etnografii dzieciństwa, socjologii dzieciństwa, pedagogiki i psychologii dziecka, dyskusji nad 
dzieciństwem „wynalezionym” i „odkrytym na nowo” oraz wielu „przełomów” w badaniach związanych z eksponowaniem interdyscyplinarności w tychże badaniach (od pracy Ellen Key, przez Janusza Korczaka, po Philipa Ariésa czy Paula Hazarda) wiedza o literaturze dla dzieci i młodzieży, a z czasem także i wiedza o kulturze dziecka znalazły się wreszcie w programach kształcenia polonistycznego na studiach uniwersyteckich.

W czasach nowożytnych dodatkowy materiał źródłowy w obrębie tego przedmiotu stanowiłyby również pamiętniki i wspomnienia, pozwalające wnikać w świat przeżyć dziecka, zarówno ludycznych, jak i traumatycznych, nierzadko obarczonych stygmatem tabu. Osobne miejsce zajmowałaby tu nie tylko literatura, której tematem jest kultura pamięci i przeszłości, ale także świadectwa dzieci z okresu holocaustu (zagadnienie to jak wiemy - weszło już na stałe do repertuaru szkolnej edukacji polonistycznej).

Nasza współczesność, niosąca młodym pokoleniom wielorakie zagrożenia (kryzys rodziny, narkotyki, molestowanie seksualne, prostytucja dziecięca, bezdomność, sekty religijne, wyzysk poprzez pracę, rozpasanie konsumpcyjne, uzależnienie od Internetu itp.), to już domena socjologii dzieciństwa i dorastania, ale także związana mocno z antropologią dzieciństwa. W obszarze polityki dzieciństwa natomiast należałoby usytuować takie zagadnienia, jak ochrona praw dziecka, ingerencja rządów w jego wychowanie i edukację czy też wykorzystywanie nieletnich żołnierzy w konfliktach zbrojnych.

Wszystkie wymienione powyżej aspekty wskazują na fakt, iż narodziła się wielka potrzeba wyłonienia nowej dziedziny wiedzy o dzieciństwie - przedmiotu o charakterze interdyscyplinarnym (child studies, children studies), uwzględniającego niedoceniane do tej pory aspekty: historyczny, socjologiczny, politologiczny i etnograficzny, połączonego wyraźnie - szerzej - z antropologią pedagogiki i edukacji.

Słowa kluczowe: Antropologia dzieciństwa, child studies, antropologia pedagogiki, socjologia dzieciństwa, polityka dzieciństwa, historia dzieciństwa, wiedza o kulturze dziecka

Our article aims to present what place the anthropology of child and childhood (within the programme of teaching specialization) may take in Polish studies of the 21st century.

After many years of laborious research on children's culture, children's folklore, ethnography of childhood, sociology of childhood, and children's pedagogy and psychology, after the discussions about "childhood reinvented" and many "breakthroughs" in studies about the interdisciplinary nature of such research (from the works of Ellen Key and Janusz Korczak, to Philippe Ariés and Paul Hazard) (Key 2005; Aries 2010; Hazard 1963; Korczak 2007), knowledge of children's and youth literature and of children's culture eventually became a part of Polish studies' programmes at the university level (Norton 2003, Kiefer 2010; Galda, Cullinan, Sipe 2006; Sipe 2008).

It took place in the second half of the 1970s, when the teaching specialization was introduced. On top of psychology, pedagogy and methodology of teaching, such knowledge was meant to prepare students for teaching Polish culture and language in elementary schools, which is mostly based on texts written specifically for children. That change showed a need for new textbooks and for specialized academic staff, as so far the specialization had been taught by pedagogy experts, which implied a focus on 
instrumental functions of children's literature and related educational systems and goals. The change in Polish studies shifted the focus to literary studies, especially the aesthetic aspect of literature that is connected with inherent poetics and the historico-literary process. The first to emerge was the history of children's and youth literature, which from the methodological perspective was a reflection of general history of literature - with its characteristic hierarchy that is more interested in lives and works of most prominent writers, and development of periodical press and literary critique within movements of the period, than in historical poetics or broad cultural contexts of texts. It was because of literary communication and works of Edward Balcerzan, Stanisław Barańczak and Jerzy Cieślikowski that the category of child's recipient within the text was coined (Balcerzan 1973; Barańczak 1973; Cieślikowski 1974). Cieślikowski advanced the research by placing such a recipient within its relevant cultural and historical contexts. It helped question the established periodization of the history of children's literature, which cannot be limited to a framework defined by important historical events. It also helped define children's literature not only in relation to literary and pedagogical trends, but first and foremost in relation to children's subculture seen as a domain of fun, which encompasses child's ludic imagination, and the need for games and other forms of creative expression that are a source of fun. Cieślikowski's works helped make an anthropological breakthrough in the concept of child as a recipient of literature, acknowledging that the child and childhood are not only existential and psychophysical categories, but also the essence of art that aims to educate (literacy tuition), entertain, and bring back the paradise lost. Therefore, Cieślikowski called for foundation of paidology, that is an interdisciplinary field of knowledge aimed at studying "the child, childhood, and works for children and by children" (Cieślikowski 1979). The child, as homo ludens, was acknowledged as a measure of worth of literature and art for non-adults.

Another anthropological breakthrough is taking place right now. It began when a famous French historian and demographer Phillippe Ariès published his work titled L'enfant et la vie familiale sous l'ancien regime (1960), in English known as Centuries of Childhood. In this book the author suggests that childhood is something more than a biologically and psychologically conditioned period of human development; it is also a cultural construct shaped by religious, social and civil changes. Childhood needs were ignored in medieval societies and then discovered during the Renaissance, which manifested itself also in art. However, Ariès fails to mention fiction for children, which emerged in the 18th century thanks to French tutors. This topic was, however, of interest to a French historian of ideas Paul Hazard, the author of an article titled Les livres, les enfants et les hommes (1931, English title: Books, Children and Men) where he expressed scathing criticism of the aforementioned "tutors' literature", since it had been 
refused by children, who had preferred books valued by adults, such as Don Quixote, Gulliver's Travels, Robinson Crusoe or Baron Munchausen. As if anticipating Ariès's approach, Hazard titled the first two chapters as follows (own translation): "Chapter 1. Men Have Always Oppressed Children" and "Chapter 2. How Children Fought Against Adults". This opposition between overtly didactic literature for children and freely chosen literature that reflects their emotional needs, elevated children's literature to the level of countercultural defiance. In Cieślikowski's works, this opposition is reflected in the juxtaposition between Stanisław Jachowicz's moralizing tale for children, which represses their spontaneity, and Juliusz Słowacki's fable about Janek who made shoes for dogs (in: Kordian), which promotes nonconformist attitudes. In both cases the focus is the literary construct of childhood, which is understood differently by the bourgeoisie (the Biedermeier mentality) and by the gentry (Romantic) mentality. However, historians of childhood are more interested in the status of the book in the intelligentsia or gentry families of the time than in the book itself. They also study family relations between parents and children, home education, day routine of the child, child fashion, toys, games, food, hygiene, etc. ${ }^{1}$.

This is why, besides homo ludens, we should mention, as Grzegorz Leszczyński did, other cultural images of the child: homo legens, homo domesticus, homo scholasticus, homo artifex. (Leszczyński 2006; Badinter 1980; Flandrin 1998; Żołądź-Strzelczyk 2002, 2008, 2010; Pachocka 2009).

In modern times, an additional source of materials are journals and memoirs, which help better understand both traumatic and ludic experiences of the child, which often appear to be taboo. A special place is reserved for children's reports of the Holocaust. However The Diary of a Young Girl (1947, 1952 in English) was very seldom an obligatory school reading in Poland (nonetheless, the subject of war and the Holocaust is nowadays present in many textbooks ${ }^{2}$ ). This is also true for memoirs of Polish children that were deported to the USSR during the war. Moreover, in recent decades we have witnessed a growing number of memoirs about growing up in the Polish People's Republic - they are an intriguing counterpoint for children's literature of that period, which often distorted the reality $^{3}$ (Górnicka-Boratyńska 2010). An extraordinary book that could enrich the list of obligatory readings is Jacek Dukaj's Wroniec (2009, trans. Crowman). This is a quasi-memoir, dark phantasmagoria about the Martial Law period in Poland, presented from the perspective of the culture of

${ }^{1}$ A proof of it may be an impressive series of monographs, mostly by French writers, under the common title "Daily Life in...". Nearly every text contains chapters on children and their upbringing. Another example is a monumental, 5-volume work titled Histoire de la vie privée [trans. History of Private Life], Ariès P. and Duby G. (ed.), 1985- 1999.

2 Including fragments of Emmanuel Schmitt's Noah's Child, fragments of Roma Ligocka's The Girl in the Red Coat, Markus Zusak's The Book Thief, and short-stories by Ida Fink (such as The Garden That Floated Away, Warszawa 2002).

${ }^{3}$ See: photography exhibition "Childhood in the Polish People's Republic": http://swidnica24.pl/ dziecinstwo-w-prl-u-w-galerii-swidnickiej/ [accessed on 14.11.2015]; One can learn a lot about the daily life in the Polish People's Republic from the novels by A. Bahdaj, E. Niziurski, Z. Nienacki or K. Siesicka. 
remembrance (both collective and individual) - it is a grotesque depiction of a totalitarian system enriched with surreal illustrations.

Our times, which bring many threats to the young (crisis of family, drugs, sexual abuse, child prostitution, homelessness, religious sects, exploitation at work, excessive consumerism, Internet addiction, etc.), are a domain for sociology of childhood and adolescence (Matyjas 2006, Zwoliński 2012). Still, literature provides many examples of such threats, as convincingly described by Grzegorz Leszczyński ${ }^{4}$, among other authors. Speaking of specific titles, we should mention Marcin Szczygielski's Czarny Młyn [trans. The Black Windmill] (2011), Anna Onichimowska's Hera, moja miłość [trans. Hera, My Love] (2003) and Lot Komety [trans. Flight of the Comet] (2007), John Green's Looking for Alaska (2005), and M. J. Hyland's Carry Me Down (2005), E. Przybylska's Dzień kolibra (The Day of Humming-bird) (1997).

In terms of the politics of childhood, we should mention such issues as children's rights protection, governments' influence on education and upbringing, or military use of children. (Carrisi 2007; Leszczyński 2010; Papuzińska, Żurakowski 1985).

Obviously, this is not an exhaustive list of disciplines connected with childhood. Before they emerged and complemented history of pedagogy and sociology of education, there existed ethnographic studies on customs and practices connected with birth and upbringing in exotic and/or indigenous cultures, which were not influenced by norms of the so-called western civilization. Children's folklore was the first to be noticed when German Romantics took an interest in it. Only later did that interest include customs connected with birth and inclusion of the child to tribal/family/communal life of adults - the latter usually entailed specific rites of passage the child had to undergo (Mead 1929; Malinowski 1984; Eliade 1909; Biegeleisen 1929; Simonides 1988; Gennep 2006). Such studies have an ethnographic and historical value, similarly to works about traditional games and toys for children - these ludic needs, however, are today satisfied with different means (television, comic books, computer games, the Internet), which is a research subject in sociology of childhood (Maciejewska-Mroczek 2012; Zasacka 2008).

Therefore, it seems a new field of knowledge about childhood is needed, a field that takes into consideration the following, previously neglected aspects: historical, sociological, political-scientific, and ethnographic. In the English-speaking world, this field of knowledge is referred to as children studies (Szymborska 2014), however we would like to propose a different name - anthropology of childhood. This name is analogous to Polish well-established names of such interdisciplinary fields as anthropology of words, anthropology of body, or anthropology of performing arts - fields that are already present in academic programmes. In the case of children's

${ }^{4}$ The scholar interprets the net-generation's prose of initiation, discusses axiologically lost characters, and describes issues that make up the ethical complexity of the modern world (the chapters of his book have significant titles, such as: "Generation nobody", "Meeting yourself, meeting the Other", "Game of values", "Literature of anthropological sensitivity", "The great escape"). 
literature, as seen by Polish teachers and educationalists, history of childhood lets us pose questions about its origin and development as related to the process of discovering the nature and needs of the child (which may also be a subject of texts for adult readers). The sociological aspect helps study children's literature in relation to, for instance, contemporary morality. The political-scientific aspect reveals connections with contemporary ideologies and politics. Finally, the ethnographic aspect aims to show relations to exoticism, initiation practices, folk pedagogy (folklore for children), and children's sub-culture (children's folklore).

Martin Woodhead writes [own translation]:

Interest in "childhood research" is sometimes regarded as a result of frustration over fragmentary depiction of childhood in academic discourse, over research methods, and as an objection to the traditional "division" of childhood between psychology, sociology, and anthropology. These disciplines objectify childhood and submit it to such constructs as developmental processes, socialization, and acculturation. The call for interdisciplinary research on childhood entails a more integrated approach to research and education, as they are connected with life and welfare of children; it also calls for a more "shared and common" vision of "the child in context", which has become a priority also for politics and professional education (Woodhead 2008, 12).

***** $*$

Dynamically developing research within children studies in Western Europe and the USA emphasizes the role of school as a public institution whose aim is, among other goals, to describe, analyse, and promote children's culture $^{5}$ (Kehily 2008; Mouritsen, Qvortrup 2002). At the end of our deliberations, we should mention Russian childhood studies that led to emergence of another new discipline called pedagogic anthropology. It stands for knowledge about man, which is meant to facilitate education of children (in its broad definition, it entails school education), and is based on the assumption that a specific character of any human being is shaped in childhood and manifests itself through common but regular symptoms, such as: child's whims, fears, reading choices, formation of one's sexual identity, religiousness, or modes of upbringing and education.

In a Russian textbook on pedagogic anthropology, a thematic selection of autobiographical fragments (written by people from different classes, professions, and nations of Europe) is preceded with a suitable introduction, while the student, having read them, is supposed to answer a number

${ }^{5}$ According to the Danish scholars (Mouritsen and Qvortrup), the child's culture is formed by: a/ adults and their specific understanding of "quality" of products for children and their purposes: educational, entertaining, artistic; b/ adults and children; $\mathrm{c} /$ children only. When analysing the modern culture of the child, it is worth looking at web portals for children and adults (e.g. www.czasdzieci. pl), where one can notice as their (i.e. children's and adults' - parents, teachers, educationalists; here not only as carers but also consumers) interests converge. See J. Qvortrup, Child Culture - Play Culture - Sociology of Childhood: Conceptual Liberation, 2002, in: Childhood and Children's Culture, ed. by Flemming Mouritsen and Jens Qvortrup, University Press of Southern Denmark. 
of questions. Some of the examples are as follows: What reasons persuade writers to share autobiographical reflections? Who defines professional future of an individual better - a child, a parent, a teacher, a psychologist...? In your childhood, have you ever experienced the challenge of overcoming yourself, training your willpower, etc.? What helped to you in such situations? To what extent do education theories you know answer the question of how to cope with child's whims? What is the role of fear in children's games and imagination? Who chose readings for you when you were a child and in what manner were they chosen? Is there a connection between the state of infatuation and creativity? If so, what is that connection? As a child, what was your relation to God? What emotions and feelings define the relation between the child and their parents? What can cause child's negative attitude to school? (Bim-Bad, Koszeleva 1988).

\section{ACADEMIC PROPOSITIONS}

As an academic course, anthropology of childhood may adopt the following subjects and highlight the aspects mentioned below:

1. Study of the child and childhood as a socio-cultural phenomenon which includes the following issues:

b. childhood as an experience;

c. child and childhood as an artistic and literary construct;

d. historical and social dimensions of childhood;

e. child's subjectivity in various educational systems;

f. formation of human rights, political interventions;

g. analysis of notions about childhood, and reconstruction of children's individual points of view (James 2008).

2. Study on socio-cultural differences in the notion of childhood:

a. traditional approach (processes of socialization and education);

b. a global perspective (e.g. discussions about multiculturalism, migration, war, gender, adoption, the media and technology; including such topics as "street children" or "child soldiers"

3. The concept of the child as a subject of social life, coming from critique/revision of fields traditionally associated with research on childhood: developmental psychology and pedagogy (Lenzer 2001). At this point we should mention Freudian attention to child sensualism, and exploration of early childhood and its traumatic characters, which were crucial for the development of childhood research at the end of the $19^{\text {th }} \mathrm{c}$. "Regardless of discoveries that became widespread in the 20th c., this subject had been present in literature even earlier, in various forms but usually in an indirect 
way (e.g. L. Carroll, Alice in Wonderland, 1865 or J. Barrie, Peter Pan -1911)" (Sztachelska 2014, 49).

4. Thought about the child that is based on an ontological and epistemological difference between "childness" and so-called "adulthood"

At the turn of the 19th century, "the banner of childhood, that cult of youth, energy and immaturity that appeared in names of new literary groups (Young Scandinavia, Young Germany, Young Poland, Jugendstill), undoubtedly masked the crisis of culture" writes Jolanta Sztachelska (Mills J., Mills E. 2000; Cataluccio 2006; Paczoska 2004).

5. Children's readings as formative factors (here: from the patriarchal to the feminist model - a gender perspective) (LasońKochańska 2012).

6. The child and art (here: childhood as represented in paintings, music, films, etc.) (Bobowski 2012).

7. Geography of childhood (categories of place and space) a topographic turnaround in research on anthropology of childhood (geopoetics, cultural geography, place studies, urban studies) (Rybicka 2008).

8. An ethical turnaround - an ethical dimension of social research on the child and childhood, ethics of authenticity - a subject studied by, among other authors, a philosopher Charles Taylor (an expert on individualism), a childhood sociologist Doris Bühler-Niederberger, and a literary scholar Lisa Sainsbury ${ }^{6}$ (Bühler-Niederberger 2004; Sainsbury 2013; Yokota 2010).

9. Comprehension and description of the phenomena of child and childhood in the context of the most important aspects of modern culture (e.g. in popular and mass culture; in the traditional and new media; the child as an interactive recipient); and the attempt to recreate the category of childhood in a fluid, ever-changing reality (Ohar, Michułka 2013/2014).

A number of specific and hard to define traits might pose a challenge in creating a cultural image of the child, while at the same time they will play a significant role in that process (Sztachelska 2014). These traits are as follows:

1. Age categories of children - "this trait is concerned with an unspecified boundary between childhood and adolescence or adulthood, which is nowadays freely and often redefined" (Sztachelska 2014, 51).

${ }^{6}$ Among Polish examples, we recommend novel written by Tomasz Tryzna - Panna Nikt [trans. Miss Nobody] (1996). 
2. Child's wildness - "this trait arises from Rousseau's thought that emphasizes the unclear origin of the child's odd behaviour, amorality, asocial nature" (e.g. Kaspar Hauser - "orphan of Europe", a man from nowhere, of unknown identity, wild, illiterate, a Tarzan figure, Mowgli - protagonist of Kipling's The Jungle Book. A pop-culture version of such a character can be found in Nell, a 1994 film by Michel Apted).

3. Indeterminacy of child's social role - "this trait highlights child's irrationality in terms of comprehending the world around them, unfamiliarity with social rules; it is the basic assumption to understand the child as an [individual - D.M.] that exists [in a way - D.M] in the margin of social life" (Sztachelska, p. 51).

In research on the cultural image of the child and anthropology of childhood, the following aspects, however they are difficult to study and define, will play a key role: imagination, and child's sensitivity and emotionality. As Sztachelska claims, their sources are always fascinating, despite being natural, unidentified, and sometimes "dark".

In conclusion, not only a childhood historian but also a teacher (of the humanities) - despite studying them from a different perspective - should treat these issues similarly and draw similar conclusions. Since not the labels are important here, but the attitude of the scholar, who sees childhood as a world of the Other who needs to be understood and familiarized with it.

\section{Bibliografia}

Ariés Philippe, 2010, Historia dzieciństwa [trans. Centuries of Childhood. A Social History of Family Life], Ohab M. (trans.), Warszawa.

Badinter Elizabeth, 1980, L'Amour en plus. histoire de l'amour maternel (XVIIeXXe siècle) [trans. History of Maternal Love], Paris; Histoire des pères et de la paternité, [trans. History of Fathers and Fatherhood], Delumeau J., Roche D. (ed.), Paris, (Historia miłości macierzyńskiej, Choiński K. (trans.), Warszawa 1998)

Balcerzan Edward, 1973, Odbiorca $w$ poezji dla dzieci, [trans. The Recipient in Poetry for Children], w: Poezja i dziecko, Poznań.

Barańczak Stanisław, 1973, Język dziecięcy a poezja dla dzieci, [trans. Children's Language and Poetry], in: Poezja i dziecko. Materiały sesji literacko-naukowej [trans. Poetry and Child. Materials from a Literary-Academic Session], Poznań.

Biegeleisen Henryk, 1929, Matka i dziecko w obrzędach, wierzeniach i zwyczajach ludu polskiego, [trans. Mother and Child in Polish Rituals, Beliefs and Customs], Lwów.

Bühler-Niederberger Doris, 2004, The Radicalization of the Self-from "Totzkopf" to "Julia Nobody". Individualization and Aestheticalisation, the Change of the Self Ideal in the Children's Literature, in: Metodyka a nauka 
o literaturze i nauka o języku, [trans. Methodology, Literary Research and Linguistic Research], Michułka D., Bakuła K. (ed.), Wrocław.

Carrisi Giuseppe, 2007, Dzieci-żołnierze. Kalami idzie na wojnę, [trans. The Child Soldiers. Kalami Goes to War. Original title: Kalami va alla guerra. I bambini soldato], Kreczko K. (trans.), Kraków.

Cataluccio Francesco, 2006, Niedojrzałość. Choroba naszych czasów, [trans. Immaturità. La malattia del nostro tempo], Kasprzysiak S. (trans.), Kraków.

Child Culture - Play Culture - Sociology of Childhood: Conceptual Liberation, 2002, in: Childhood and Children's Culture, Flemming Mouritsen and Jens Qvortrup (ed.), University Press of Southern Denmark.

Childhood Studies. A Reader in Perspectives of Childhood, 2000, Mills J., Mills E. (ed.), London.

Cieślikowski Jerzy, 1979, Przedmiot, metody i sposoby badania literatury dla dzieci. Propozycje metodologiczne do badań nad literacka twórczościa dla dzieci, [trans. Subject, Methods and Research Techniques of Children's "Literature"], in: Sztuka dla dzieci szkolnych: teoria - recepcja - oddziaływanie, [trans. Art for School Children: Theory - Reception Influence], Tyszkowa M. (ed.), Warszawa - Poznań.

Cieślikowski Jerzy, 1974, Literatura i podkultura dziecięca, [trans. Children's Literature and Subculture], Wrocław.

Clarke John, 2004, Histories of Childhood, in: Childhood Studies. An Introduction, Wyse D. (ed.), Oxford.

Dawne zabawy dziecięce, 2008, [trans. Old Children's Games], Żołądź-Strzelczyk D., Kabacińska K. (ed.), Warszawa - Kielce.

Dawne i współczesne zabawki dziecięce, 2010, [trans. Old and Modern Toys for Children], Kabacińska K., Żołądź-Strzelczyk D. (ed.), Poznań - Kielce.

Dziecko w dawnej Polsce, 2002, [trans. The Child in Old Poland], Kabacińska K., Żołądź-Strzelczyk D. (ed.), Poznań.

Dziecko w kulturze współczesnego świata, 2013, [trans. The Child in the Modern World's Culture], Jagiełło E., Jówko E. (ed.), Siedlce.

Dziecko $w$ rodzinie i społeczeństwie, starożytność i średniowiecze, 2002, [trans. The Child in the Family and Society. Antiquity and Middle Ages], Jundziłł J., Żołądź-Strzelczyk D. (ed.), Bydgoszcz.

Dziecko w świecie mediów, 2003, [trans. The Child in the World of the Media], in: "Edukacja i dialog", nr 6.

Eliade Mircea, 1997, Lesrites de passage (1909), (Polish title: Inicjacja, obrzędy, stowarzyszenia tajemne. Narodziny mistyczne, Kocjan K. (trans.), Kraków.

Film dziecięcy, dziecko w filmie, 2012, „Studia Filmoznawcze”, [trans. Children's Film, The Child in the Film, Film Studies], issue 33, Bobowski S. (ed.), Wrocław.

Flandrin Jean -Louis, 1998, Familles. Parenté, maison, sexualité dans l'ancienne société, [trans. History of Family. Kinship, home, sexuality in the old society], Historia rodziny, Kuryś A. (trans.), Warszawa, 
Gennep Arnold, 2006, Obrzędy przejścia. Systematyczne studium ceremonii..., [trans. Rites of Passage], Biały B. (trans.), Warszawa.

Górnicka-Boratyńska Aneta, 2010, Zielone pomarańcze czyli PRL dla dzieci, Butenko B. (il.), [trans. Green Oranges, or Childhood in the Polish People's Republic], Warszawa.

Hazard Paul, 1963, Książki, dzieci i dorośli, [trans. Books, Children and Men], Słońska I. (trans.), Warszawa.

James Allison, 2008, Childhood Studies, in: James A., Key Concepts in Childhood Studies, London.

Korczak Janusz, 1993, Dzieła, Tom 7, Jak kochać dziecko. Momenty wychowawcze. Prawo dziecko do szacunku, [trans. Works Vol. 7. How to Love a Child. Formative Moments. Child's Right to be Respected], Warszawa.

Korczak Janusz, 2007, Dzieła, Tom 11. Vol 2. Prawidła życia. Publicystyka dla dzieci, [trans. Works Vol. 11. Tome 2. Rules of Life. Articles for Children]. Warszawa.

Kehily Mary Jane, 2004, Wprowadzenie do badań nad dzieciństwem, [trans. An Introduction to Childhood Studies], Kościelniak M. (trans. rev.), Kraków.

Key Elen, 2005, Stulecie dziecka, [trans. The Century of the Child], Warszawa.

Kiefer Barbara, 2010, Charlotte Huck's Children's Literature, McGraw - Hill.

Lasoń-Kochańska Grażyna, 2012, Gender w literaturze dla dzieci i młodzieży. Wzorce płciowe i kobiecy repertuar topiczny, [trans. Gender in Literature for Children and Youth. Gender Models and Women's Topical Repertoire], Słupsk.

Lee Galda, Cullinan Bernice E., Sipe Lawrence R., 2006, Literature and Child, Wadsworth.

Lenzer Gertrud, 2001, Children's Studies: Beginnings and Purposes, "The Lion and the Unicorn", vol. 25.

Leszczyński Grzegorz, 2006, Kulturowy obraz dziecka i dzieciństwa $w$ literaturze drugiej połowy XIX i w XX wieku. Wybrane problemy, [trans. The Cultural Image of Child and Childhood in the Literature of the Second Half of $19^{\text {th }}$ Century and of the $20^{\text {th }}$ Century], Warszawa.

Leszczyński Grzegorz, 2010, Bunt czytelników. Proza inicjacyjna netgeneracji, [trans. The Readers' Rebellion. The Net-Generation's Prose of Initiation], Warszawa.

Maciejewska-Mroczek Ewa, 2012, Mrówcza zabawa. Współczesne zabawki a społeczne konstruowanie dziecka, [trans. Ants' Play. Modern Toys and Social Creation of the Child], Kraków.

Malinowski Bronisław, 1984, The Sexual Life of Savages in North-Western Melanesia. An Ethnographic Account of Courtship, Marriage, and Family Life Among the Natives of the Trobriand Islands, Chałasiński J., Waligórski A. (trans.), Warszawa. 
Matyjas Bożena, 2006, Dzieciństwo w kryzysie. Etiologia zjawiska, [trans. The Crisis of Childhood. Etiology of the Phenomenon], Warszawa.

Mead Margaret, 1928, Coming of Age in Samoa and Growing up in New Guinea [1925-1926], New York.

Norton Donna E., 2003, Through the Eyes of a Child, New Jersey.

Ohar Emilya, Michułka Dorota, 2013/2014, "The Child and the Modern World of 'Digital Resources' (Manners of Perception)”, in: Filoteknos, Kołodziejczyk D., Branson S., Michułka D., Waksmund R. (ed.), issue 4, Wrocław.

Pachocka Anna, 2009, Dzieciństwo we dworze szlacheckim w I połowie XIX wieku, [trans. Childhood at the Gentry Estate in the First Half of the 19th Century], Kraków.

Paczoska Ewa, 2004, Dojrzewanie, dojrzałość, niedojrzałość. Od Bolesława Prusa do Olgi Tokarczuk, [trans. Maturation, Maturity, Immaturity. From Bolesław Prus to Olga Tokarczuk], Warszawa.

Prirodariebionka $w$ zierkaleawtobiografii. Uczebnoje posobije po piedagigiczeskoj antropologii, (trans. The Nature of a Child as Reflected in the Mirror of Autobiography. A Teaching Aid in Educational Anthropology), 1988, Bim-Bad B.M., Koszeleva O. (ed.), Moskwa.

Rybicka Elżbieta, 2008, Od poetyki przestrzeni do polityki miejsca. Zwrot topograficzny $w$ badaniach literackich, [trans. From the Poetics of Space to Politics of Place. A Topographical Change in Literary Research], in: "Teksty Drugie", issue 1-2.

Sainsbury Lisa, 1996, Ethics in British Children's Literature: Unexamined Life, London 2013.

Simonides Dorota, 1988, Od kolebki do grobu: śląskie wierzenia, zwyczaje i obrzędy rodzinne w XIX wieku, [trans. From Cradle to Grave: Silesian Beliefs, Customs and Family Rituals in the $19^{\text {th }}$ Century], Opole.

Sipe Lawrence R., 2008, foreword by P. David Pearson, in: Story Time: Young Children's Literary Understanding in the Classroom, Columbia University.

Sztachelska Jolanta, 2014, „Dziwność” dziecka (rzecz o imaginarium społecznym) [trans. „Strangeness” of the Child (About Social Imaginarium)], in: Children Studies jako perspektywa interpretacyjna. Studia i szkice, [trans. Children Studies as an Interpretive Perspective. Studies and Sketches], Sztachelska J., Szymborska K. (ed.), Białystok.

Szymborska Karolina, 2014, W metodologicznym tyglu 'children studies', [trans. In the Methodological Pot of Children Studies], in: Children Studies jako perspektywa interpretacyjna. Studia i szkice, [trans. Children Studies as an Interpretive Perspective. Studies and Sketches], Sztachelska J., Szymborska K. (ed.), Białystok.

Taylor Charles, 1996, Etyka autentyczności, [The Ethics of Authenticity], Pawelec A. (trans.), Warszawa.

Temple Charles, Miriam Martinez, Junko Yokota, 2010, Children's Books in Children's Hands, Chicago. 
The Sexual Life of Savages in North-Western Melanesia. An Ethnographic Account of Courtship, Marriage, and Family Life Among the Natives of the Trobriand Islands, 1984, Chałasiński J., Waligórski A. (trans.), Warszawa.

W kreqgu rodziny epok dawnych [trans. About Family of Older Times], 2014, Popiołek B., Chłosta-Sikorska A., Gadocha M. (ed.), Kraków.

Waksmund Ryszard, 1994, Dzieci - plemię nieznane. Od folklorystyki do etnografii dzieciństwa, [trans. „Children - An Unknown Tribe. From Folklore Studies to Ethnography of Childhood], "Literatura Ludowa”, issue 4. Wrocław.

Wartości literatury dla dzieci i młodziė̇y, [trans. Values of Literature for Children and Youth], 1985, Papuzińska J., Żurakowski B. (ed.), Warszawa Poznań.

Woodhead Martin, 2008, foreword in: Wprowadzenie do badań nad dzieciństwem, [trans. An Introduction to Childhood Studies], Kehily M.J. (ed.), Kościelniak M. (trans. rev.), Kraków.

Zasacka Zofia, 2008, Nastoletni czytelnicy, Warszawa.

Zwoliński Andrzej, 2012, Dzieci krzywdzone. Zagrożenia współczesnego dzieciństwa, [trans. Harmed Children. Dangers of Modern Childhood], Kraków.

\section{O Autorach:}

Dorota Michułka - dr hab., Kierownik Zakładu Metodyki Nauczania Języka i Literatury Polskiej w Instytucie Filologii Polskiej na Uniwersytecie Wrocławskim; jest polonistką i historykiem; zajmuje się historią literatury, literaturą dla dzieci, kształceniem literacko-kulturowym (także w ujęciu historycznym), szkolną recepcją literatury i kultury, edukacją humanistyczną w perspektywie socjo-kulturowej; w latach 2000- 2005 pracowała jako lektorka języka polskiego na Uniwersytecie w Tampere (Finlandia); przebywała na stypendiach w Holandii (Department of Social Science Leiden) i USA (University of Minnesota); autorka dwóch monografii [ostatnia Ad usum Delphini. O szkolnej edukacji literackiej - dawniej i dziś (2013)], kilku redagowanych i współredagowanych edycji, 130 artykułów w tym ok. 20 opublikowanych za granicą; z-ca - redaktora naczelnego międzynarodowego czasopisma „Filoteknos. Children's Literature - Cultural Mediation - Anthropology of Childhood"; od 15 lat - członek Międzynarodowego Towarzystwa do Badań nad Literaturą dla Dzieci (IRSCL, International Society Research on Childrens Literature).

Ryszard Waksmund - prof. Uniwersytetu Wrocławskiego w Zakładzie Literatury Ludowej, Popularnej i Dziecięcej oraz Wydziału Lalkarskiego krakowskiej Państwowej Wyższej Szkoły Teatralnej z filią we Wrocławiu, historyk literatury dziecięcej, uczeń prof. Jerzego Cieślikowskiego. Jego prace dotyczą $\mathrm{w}$ większości badań nad poetyką historyczną twórczości 
dla niedorosłych - od jej oświeceniowych początków po wiek XX. Należą do nich głównie książki: Literatura pokoju dziecinnego (1986), Nie tylko Robinson, czyli o oświeceniowej literaturze dla dzieci i młodzieży (1987) oraz Od literatury dla dzieci do literatury dziecięcej: tematy - gatunki konteksty (2000). Jest ponadto autorem lub współautorem antologii na użytek dydaktyki uniwersyteckiej: Literatura i podkultura dzieci i młodzieży. Antologia opracowań (z Jerzym Cieślikowskim,1983), Poezja dla dzieci. Antologia form i tematów $(1987,1999)$, Gabinet wróżek. Antologia baśni francuskich XVII-XVIII wieku (1998), Ostatni smok. Baśnie pisarzy angielskich (z Edwardem Szynalem, 2005) oraz Bajki carycy Katarzyny II dla wnuków i inne utwory baśniowe pisarzy rosyjskich XVIII wieku (z Nelly Staffa, 2007). Redaguje periodyk „Filoteknos: literatura dziecięca - mediacja kulturowa - antropologia dzieciństwa”. 